[Original]

\title{
Proximity Density Assessment and Characterization of Water and Sanitation Facilities in the Informal Settlements of Kisumu City: Implications for Public Health Planning
}

\author{
Calvince O OтноO $^{1 *}$, Simeon O Dulo ${ }^{1,2}$, Daniel O OlaGo ${ }^{1,3}$ and Richard Ayah $^{4}$ \\ ${ }^{1}$ Institute of Climate Change and Adaptation, University of Nairobi, PO Box 29053-00200 Nairobi, Kenya \\ 2 Department of Civil Engineering, University of Nairobi, PO Box 29053-00200 Nairobi, Kenya \\ ${ }^{3}$ Department of Geology, University of Nairobi, PO Box 29053-00200 Nairobi, Kenya \\ ${ }^{4}$ School of Public Health, University of Nairobi, PO Box 29053-00200 Nairobi, Kenya
}

\begin{abstract}
Access to water and sanitation remain a challenge in many developing countries, especially in pro-poor urban informal settlements where socioeconomic livelihoods are generally low. The aim of this study was to characterise the water and sanitation facilities in the informal settlements of Kisumu City and to evaluate their effect on community hygiene and health. The study focussed on the five urban informal settlements of Nyalenda A, Nyalenda B, Manyatta A, Manyatta B and Obunga, and the three Peri-urban informal settlements of Kogony, Usoma and Otonglo. Using descriptive techniques, the researcher surveyed 114 water sources and all sanitation facilities within $0^{-15} \mathrm{~m}$ and $15-30 \mathrm{~m}$ radii of the water sources. The findings revealed dominance of shallow wells and traditional pit latrines as the primary water sources and sanitation facilities, respectively. Out of the water sources studied, 87.7\% (100) were shallow wells (mean depth $1.5 \mathrm{~m}$ ), 9.6\% (11) springs and 2.6\% (3) boreholes. Most of these shallow wells $(83 \%)$ were within the urban informal settlements where uses range from washing and cleaning, cooking, and even drinking (13.5\%), despite the majority being unprotected. The analysis of the density of sanitation facilities near the water points showed that $32.3 \%$ existed within a $15 \mathrm{~m}$ radius of the nearest water sources, in violation of the recommended safe distance of $30 \mathrm{~m}$. With an increased density of toilets near critical water sources and other sanitary practices, public health is highly compromised.
\end{abstract}

Keywords : density, health, informal settlements, water-source, Sanitation technology.

(Received December 2, 2019, accepted June 1, 2020)

\section{Introduction}

Inadequate water supply and poor sanitation remain widespread in low-income countries [1]. According to the latest Joint monitoring program (JMP) progress on sanitation and water report by the World health organization (WHO) and the United nations children's fund (UNICEF) [2], about $32 \%$ of the global population lack basic sanitation services, while about 159 million people still collected drinking water directly from surface sources - $58 \%$ of whom are in sub-Saharan Africa. The population with access to safely managed sanitation in sub-Sahara Africa is the lowest in the world [3], and only $28 \%$ have access to safely managed sanitation [2]. Some recent studies conducted in east and west Africa revealed even worse conditions in urban informal set-

*Corresponding Author: Calvince Ouko Отноо, Department of Community Development and Environmental Management, Co-operative University of Kenya. P.O. Box 24814 -00502 Nairobi, Kenya. Tel: +254726096564, E-mail: oukokothoo@gmail.com or couko@cuk.ac.ke 
tlements where access to basic sanitation and water was chillingly low [4-6]. Safe handling of human excreta from the point of generation to the point of use or ultimate disposal is key to efficient community sanitation management [7]. This is particularly important as there is a close association between sanitation management and water quality $[8,9]$ and hygiene $[10,11]$. Poor water quality or pollution of water sources may be due to bacterial or chemical seepage from pit latrines, and may also result from broken septic tanks, irrigation, and run-off water carrying agro-chemicals [12-16]. Notably, the spread of many infectious diseases, including cholera and typhoid, has been associated with human excreta and lack of adequate hygiene [17-19].

As already observed, urban informal settlements face diverse challenges arising from poorly managed sanitation. In Kenya, for instance, a recent governmental mid-term sanitation report showed that approximately 27 million US Dollars is spent annually on sanitation related diseases [20], and the urban informal settlement carry the largest responsibility. Urban informal settlements are characterised by poor livelihoods, congestion and lack of basic infrastructure [21]; it is, thus, not uncommon to find water sources and pit latrines in very close proximity to each other in these areas [22]. Moreover, due to increasing population pressure, sharing of sanitation facilities and frequency of filling (or emptying) of toilet facilities is notably high as well. Kisumu City is one of the Kenyan cities with the largest burden of urban informal settlements [23], and several studies have attempted to report gaps in access to and safety of drinking water in these settlements [24-26]. Despite these studies, none has conducted advanced ground surveys to identify water sources and sanitation facilities using a proximity density approach. This study, therefore, attempted to evaluate the potential public health implications of high density sanitation facilities within close proximity to critical water sources in eight informal settlements of Kisumu City.

\section{Characterising water and sanitation technologies}

Water sources have been categorised as either improved/protected or non-improved [19]. An improved water source is defined as one that by nature of its construction is protected from entry of physical, chemical and biological contamination. Protected water sources are covered by stonework, concrete or other materials that prevent the entry of physical, chemical and biological contaminants, while unprotected sources are those with no barrier to protect the water from contamination [27]. Water from unprotected sources cannot be considered safe to drink unless treated [21]. It is noteworthy, though, that many factors, such as existing geology, soils, topography and flooding risks may also directly or indirectly influence the nature and types of water sources and their quality $[10,28]$. Wells and springs draw their water from subsurface saturated zones or aquifers, which are zones bellow which there is permanent saturation of soil and rock pores with water [29, 30].

The characterization of sanitation facilities focuses on the different systems, technologies and types in use. A sanitation system includes the management, operation and maintenance required for ensuring safe and sustainable functioning of the system [7, 31]. Sanitation systems can be classified into the following categories: (a) earth/dry and water-based types, (b) context of use (i.e. shared or individual facilities), and (c) types and stability of the structures (for instance mobile and permanent facilities). A sanitation facility is the infrastructure dedicated to the disposal, conveyance or treatment of waste, while sanitation technology is the specific infrastructural configurations, methods or services designed specifically to contain, transform or transport waste to another process, point of use or disposal [7]. Sanitation facilities come in different forms and types with suitability for developing countries, the choice of which depends on variable factors such as social, economic and environment factors [32]. Examples of common sanitation facilities can be found in the literature [7, 33-35], and may include, among others: the cat method or the dig and cover type, the traditional pit latrine (TPL) which describes a simple pit latrine without any ventilation, the San-plat pit latrine, the shallow double pit compost toilet (Fossa alterna), and the ventilated improved pit latrine (VIP), which, apparently, is widely promoted in low cost settlements.

\section{Study Area and Methods}

\section{Study area}

The study was carried out in the informal settlements of Kisumu City, the principle lakeside city in western 
Kenya (Figure 1). Kisumu was established in 1898 as an alternative railway terminus for the Kenya-Uganda railway. Over the years, Kisumu has grown to be the third largest city in Kenya, with an estimated present population of 600,000 according to the recent Kenya National Population and Housing Survey of 2019 [36]. Geographically, Kisumu is situated at $34^{\circ} 20^{\prime} \mathrm{E}$ and $34^{\circ} 70^{\prime} \mathrm{E}, 0^{\circ} 20^{\prime} \mathrm{S}$ and $0^{\circ} 25^{\prime} \mathrm{S}$ [22] and lies at an altitude of between 1,160-1,400 $\mathrm{m}$ above sea level [37]. Kisumu has an annual precipitation of between 1,111-1,407 mm received in two major rainy seasons: March-May and October- December, and a subdued rainfall peak in August $[37,38]$. The temperature varies seasonally with a mean annual temperature range from $18^{\circ} \mathrm{C}$ to $20^{\circ} \mathrm{C}$ [39]. The city is surrounded by a mountain slope north of the city, wetlands in the south, and two plain belts: the Kano Plain in the south-east and Kanyakwar plain in the north. Volcanic soils occupy the mountainous areas of the Kisian hills and Riat hills towards the north and most parts of the city's central region [25].

The study focused on the urban informal settlements of Nyalenda A, Nyalenda B, Manyatta A, Manyatta B and Obunga, and the peri-urban informal settlements of Kogony, Usoma and Otonglo. Informal settlements cover approximately $19 \%$ of the city [28] and host about $60 \%$ of the city's urban population - approximately 60,000 households with a population density of between 6,000 and 21,000 persons per $\mathrm{km}^{2}$ [25]. The water table in most of the urban slums is relatively high; in fact, in the informal settlements of Manyatta and Nyalenda, the water table can often rise to depths

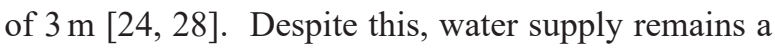
challenge in most of these informal settlements.

The informal settlements in Kisumu have a historical perspective that has changed little over the years; the settlements have remained safe-havens to poor migrants largely from neighbouring counties in search of employment opportunities in the few industrial and commercial establishments [40]. The bulk of these migrants are likely to settle in the slums, in the process adding to the pressure on the already impoverished settlements [41].

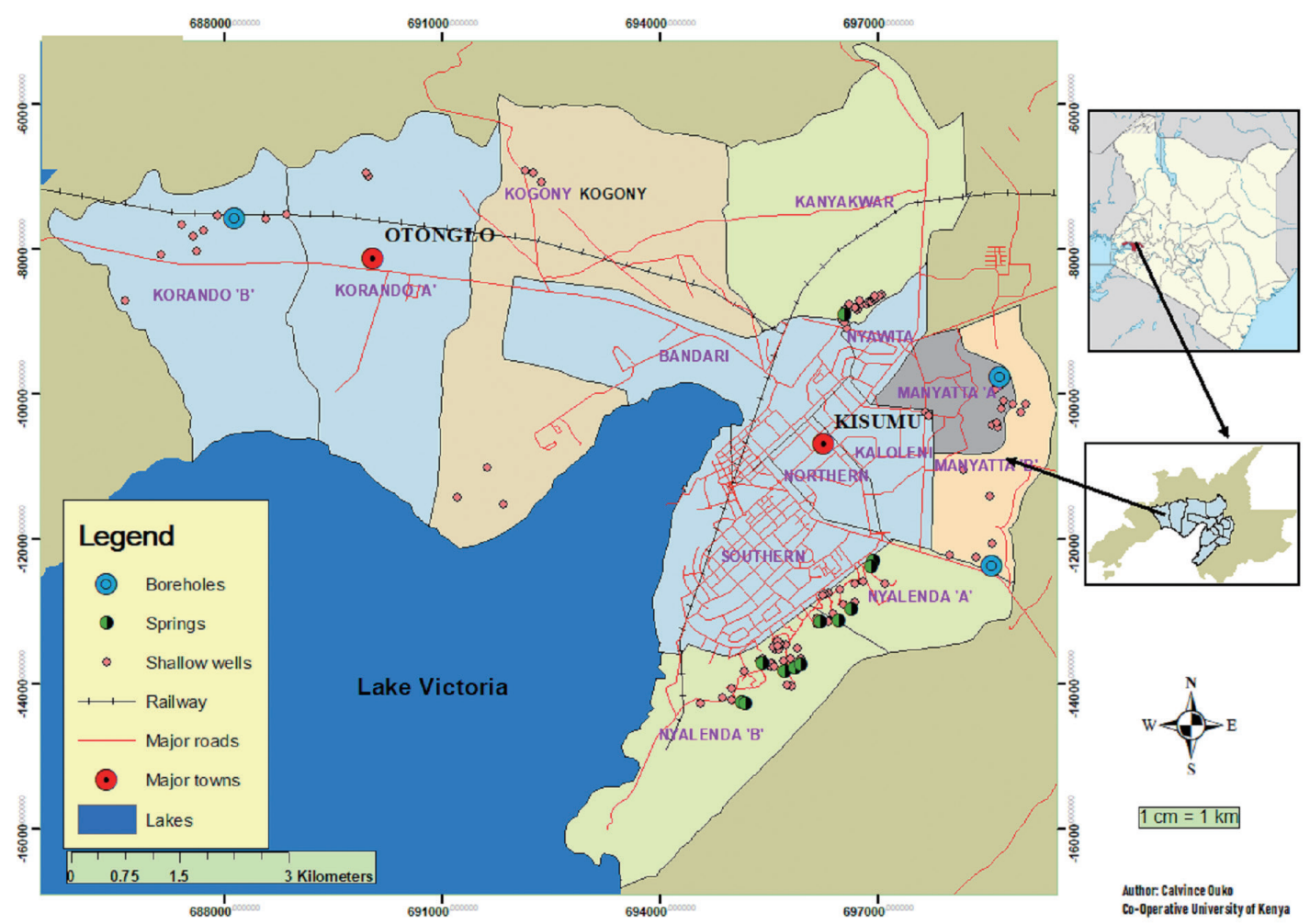

Figure 1. Map of the study area showing the urban informal settlements (Nyalenda A, Nyalenda B, Manyatta $A$ and Manyatta $B$ and Obunga) and peri-urban settlements (Otonglo, Usoma and Kogony). (Inset: map of Kenya, Kisumu County, and the areas of interest, highlighted). 


\section{Sampling techniques and data collection}

The surveys targeted all the water sources and sanitation facilities (i.e. pit latrines) in the study area. To deal with the complex settlement dynamics, the lack of defined transects paths and the high density of sanitation facilities in the study area, a multi-sampling approach involving convenience, random sampling and snowball techniques was used to identify target facilities. Convenience sampling aided the identification of water sources, from where the researcher snowballed to identify sanitation facilities in $15 \mathrm{~m}$ and $30 \mathrm{~m}$ proximity radius to water sources. Data was collected by the use of semi-structured questionnaires (or checklist of questions), a hand held GPS device, measuring tools involving measuring tape, and a $15 \mathrm{~m}$ rod of wire for measuring the depths of facilities and shallow wells. Data was entered on a pre-designed data entry matrix table. Water sources were assessed based on type, depth, abstraction methods, usage, nature of wall lining or protection existing, and, finally, the types and density of sanitation facilities in close proximity to shallow water sources and based on whether they are shared or not.

A total of 467 sanitation facilities and 114 water sources were sampled. The water sources comprised 100 shallow wells (SWs), 11 springs (Sps) and 3 boreholes (BHs), of which about $83.4 \%$ were from the urban informal settlements while the rest (16.4\%) were from control areas. Water sources were categorised as SWs or BHs, depending on the depth, or as Sps, based on the geological well classifications provided in the literature $[27,42,43]$. The term "water source" in this study exclusively refers to water sources outside the municipal supply of the Kisumu Water and Sewerage Company (KIWASCO). The depth and water level were measured by a $5 \mathrm{~m}$ long steel rod and a $50 \mathrm{~m}$ tape. For deeper wells, the well owners provided the information. Sanitation facilities within $15 \mathrm{~m}$ and 30 $\mathrm{m}$ radii of water points were recorded and their spatial coordinates were taken.

\section{Data analysis}

Quantitative data was analysed descriptively in Microsoft Excel (Microsoft, WA), and a ArcGIS buffering tool (ESRI, CA) was used to generate buffer plots (Figure 2) from where accurate proximity analysis was undertaken. Once the number of facilities within $15 \mathrm{~m}$ and $30 \mathrm{~m}$ radii were established, a percentage/ratio was calculated to represent the proximity density of facilities per study area, as shown below:

Total number of pit latrines

Proximity density $=$ within $15 \mathrm{~m}$ or $30 \mathrm{~m}$ per study site Total number of SWs

Correlation analysis assisted to test for associations between the variables, and testing of the statistical significance of the correlations was based on a $P$ value of 0.05 (95\% confidence interval). Generally, the outputs were presented under thematic classes, i.e. type of facility, method of water abstraction, number of users, type usage of water sources, nature of wall lining, and types and characteristics of sanitation facilities. In this study, the word "sanitation density" was used and interpreted as the number of pit latrines within a $15 \mathrm{~m}$ or $30 \mathrm{~m}$ radius of a SW.

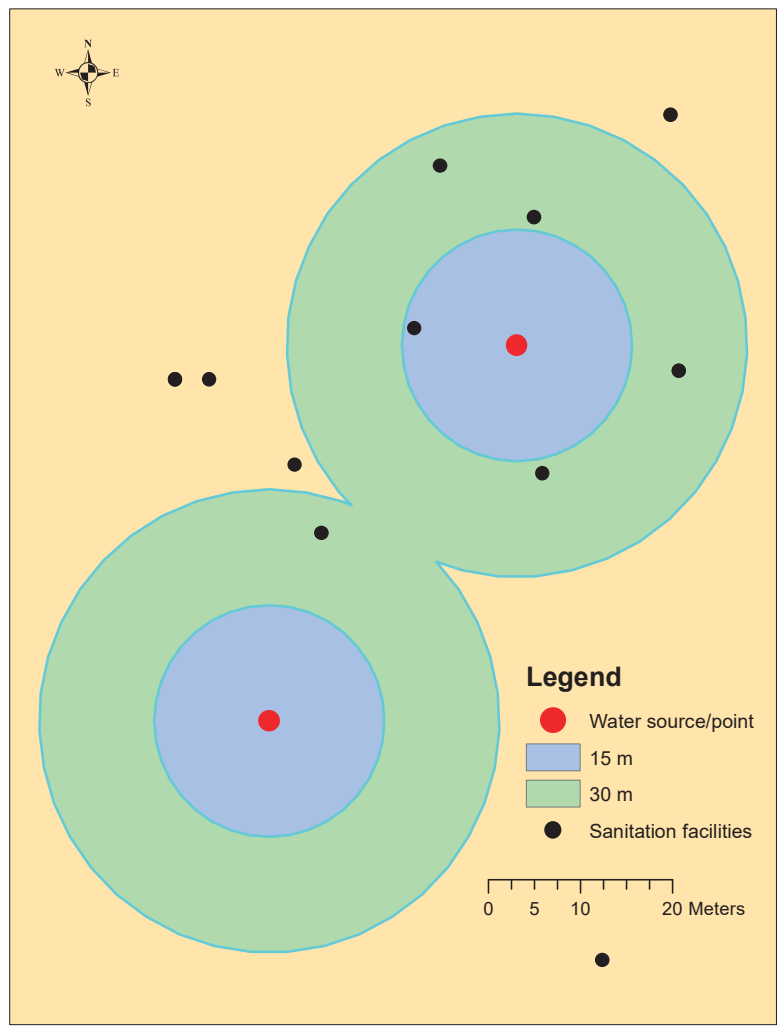

Figure 2. An illustration of the buffering procedure in ArcGIS spatial analyst tool used in calculating proximity sanitation density. 


\section{Results}

Types of water sources and methods of abstraction by users

Of the 114 water sources studied in the entire study area, 100 were SWs (87.7\% of total), 11 were Sps (9.6\%), and three were BHs (2.6\%) (Table 1). Out of the SWs, 84 (84\%) were from the urban informal settlements and the rest $16(16.0 \%)$ were from peri-urban areas. The number of SWs was the highest in Nyalenda B (24) and the least in Usoma (4) and Kogony (4). There were $11 \mathrm{Sps}$ studied in the entire study area; Nyalenda B had the highest number of Sps (6), followed by Nyalenda A (3), Obunga (1), and Otonglo (1). There were only three BHs surveyed in Manyatta A, Manyatta $\mathrm{B}$ and Otonglo. Both tables further show the relative depth and water head/level. The following types of water abstraction were observed (Table 2): hand drawing (HD), electric pumps (EP), hand pump (HP), foot pump (FP), and lever (L). Generally, HD dominates spring water abstraction, and this was observed across the en- tire study area. For all the study sites, HD was dominant (85\% cumulative) except in Kogony, where HD and L were applied equally ( $\mathrm{HD}=50 \%, \mathrm{~L}=50 \%$ ). A significant negative correlation was established $\left(\mathrm{R}^{2}=0.60\right)$ between HD as an abstraction method and depth of SWs in the study area $(P=0.003)$.

\section{Analysis of uses of water in the study area}

The major uses of water identified were: washing/ cleaning $(80.2 \%)$, followed by cooking $(42.7 \%)$, drinking (13.5\%), and, lastly, irrigation (2.1\%) (Table 3). About $75 \%$ and $71 \%$ of Nyalenda B and Nyalenda A residents, respectively, use SWs for washing and cleaning, while about $62 \%$ and $59 \%$, respectively, use the same water for cooking. Results also showed that most of the SWs attract a large number of users, especially during dry seasons, in all the areas except in Usoma and Kogony (users during dry season: Nyalenda $A=600$, Nyalenda $B=280$, and Usoma $=480$ ). Analysis of correlation showed a significant positive association between uses of SWs and depth of SWs $\left(\mathrm{R}^{2}=0.78 ; P=0.03\right)$.

Table 1. Assessment of water sources (SW and BH), depth (m), and water level (metres below ground level) in the urban and peri-urban informal settlements

\begin{tabular}{|c|c|c|c|c|c|c|c|c|c|c|c|c|c|c|c|c|}
\hline \multirow[b]{3}{*}{ Item } & \multicolumn{10}{|c|}{ Urban informal settlements } & \multicolumn{6}{|c|}{ Peri-urban informal settlements } \\
\hline & \multicolumn{2}{|c|}{ Nyalenda B } & \multicolumn{2}{|c|}{ Nyalenda A } & \multicolumn{2}{|c|}{ Manyatta B } & \multicolumn{2}{|c|}{ Manyatta A } & \multicolumn{2}{|c|}{ Obunga } & \multicolumn{2}{|c|}{ Usoma } & \multicolumn{2}{|c|}{ Kogony } & \multicolumn{2}{|c|}{ Otonglo } \\
\hline & Dth & W.1 & Dth & W.1 & Dth & W.1 & Dth & W.1 & Dth & W.1 & Dth & W.1 & Dth & W.1 & Dth & W.1 \\
\hline Number of SWs & 24 & & 17 & & 14 & & 7 & & 22 & & 4 & & 4 & & 8 & \\
\hline Min & 0.6 & 0.5 & 1.2 & 0.3 & 3.0 & 1.5 & 4.6 & 0.3 & 0.6 & 0.0 & 3.0 & 1.5 & 12.2 & 4.9 & 7.6 & 1.5 \\
\hline Max & 9.1 & 3.0 & 9.1 & 5.5 & 15.6 & 4.6 & 15.2 & 7.6 & 3.0 & 0.9 & 24.4 & 4.6 & 24.4 & 15.2 & 45.7 & 9.1 \\
\hline Median & 3.4 & 1.1 & 4.0 & 1.7 & 8.1 & 2.4 & 8.8 & 0.6 & 1.8 & 0.3 & 9.9 & 3.0 & 14.5 & 7.0 & 14.5 & 6.1 \\
\hline
\end{tabular}

SW: Shallow Well 0 $-50 \mathrm{ft}$ or 0 $-15.75 \mathrm{~m}$, Dth: depth, W.1: water level, BH: Borehole $>100 \mathrm{ft}$ or $>30.5 \mathrm{~m}$

Table 2. Summary of abstraction/water-withdrawal techniques practiced in the study area (excluding boreholes)

\begin{tabular}{llrrrrr}
\hline Settlement & Location & Number of SWs & HD & \multicolumn{1}{c}{ EP } & L & HP/FP \\
\hline Urban Informal & Nyalenda B & 24 & $23(95.8 \%)$ & $2(8.3 \%)$ & $0(0.0 \%)$ & $0(0.0 \%)$ \\
& Nyalenda A & 17 & $12(70.6 \%)$ & $2(11.8 \%)$ & $0(0.0 \%)$ & $2(11.8 \%)$ \\
& Manyatta B & 14 & $11(91.7 \%)$ & $1(8.3 \%)$ & $0(0.0 \%)$ & $0(0.0 \%)$ \\
& Manyatta A & 7 & $6(85.7 \%)$ & $1(14.3 \%)$ & $0(0.0 \%)$ & $0(0.0 \%)$ \\
& Obunga & 22 & $21(95.5 \%)$ & $1(4.5 \%)$ & $0(0.0 \%)$ & $0(0.0 \%)$ \\
Peri-urban & Usoma & 4 & $3(75.0 \%)$ & $0(0.0 \%)$ & $1(25.0 \%)$ & $0(0.0 \%)$ \\
& Kogony & 4 & $2(50.0 \%)$ & $0(0.0 \%)$ & $2(50.0 \%)$ & $0(0.0 \%)$ \\
& Otonglo & 8 & $7(87.5 \%)$ & $0(0.0 \%)$ & $1(1.25 \%)$ & $0(0.0 \%)$ \\
& Sum as \% of total & 100 & $85(85.0 \%)$ & $7(7.0 \%)$ & $4(4.0 \%)$ & $2(2.0 \%)$ \\
\hline
\end{tabular}

$\%$ of shallow wells using given abstraction techniques. HD: hand drawing, EP: electrical pumping, L: lever, HP/FP: hand pump/foot pump 
Table 3. Analysis of uses of water sources in the study area

\begin{tabular}{|c|c|c|c|c|c|c|c|}
\hline Settlement & Site & Type & $\begin{array}{l}\text { Water } \\
\text { Sources } \\
(\mathrm{n}=114)\end{array}$ & $\begin{array}{l}\text { Laundry } \\
\text { \&cleaning }\end{array}$ & Drinking & Cooking & Irrigation \\
\hline \multirow[t]{11}{*}{ Urban informal } & \multirow[t]{2}{*}{ Nyalenda B } & SW & 24 & $18(75.0 \%)$ & $3(12.5 \%)$ & $15(62.5 \%)$ & $0(0.0 \%)$ \\
\hline & & SP & 6 & $5(83.3 \%)$ & $1(16.7 \%)$ & $5(83.3 \%)$ & $0(0.0 \%)$ \\
\hline & \multirow[t]{2}{*}{ Nyalenda A } & SW & 17 & $12(70.6 \%)$ & $4(23.5 \%)$ & $10(58.8 \%)$ & $0(0.0 \%)$ \\
\hline & & SP & 3 & $2(66.7 \%)$ & $1(33.3 \%)$ & $2(66.7 \%)$ & $0(0.0 \%)$ \\
\hline & \multirow[t]{2}{*}{ Manyatta B } & SW & 14 & $12(85.7 \%)$ & $2(14.2 \%)$ & $3(21.4 \%)$ & $0(0.0 \%)$ \\
\hline & & $\mathrm{BH}$ & 1 & $1(100 \%)$ & $1(100 \%)$ & $1(100 \%)$ & $0(0.0 \%)$ \\
\hline & \multirow[t]{2}{*}{ Manyatta A } & SW & 7 & $3(42.9 \%)$ & $0(0.0 \%)$ & $1(14.2 \%)$ & $2(28.5 \%)$ \\
\hline & & $\mathrm{BH}$ & 1 & $1(100 \%)$ & $1(100 \%)$ & $1(100 \%)$ & $0(0.0 \%)$ \\
\hline & \multirow[t]{2}{*}{ Obunga } & SW & 22 & $22(100 \%)$ & $0(0.0 \%)$ & $3(13.6 \%)$ & $0(0.0 \%)$ \\
\hline & & SP & 1 & $1(100 \%)$ & $0(0.0 \%)$ & $0(0.0 \%)$ & $0(0.0 \%)$ \\
\hline & \multicolumn{2}{|l|}{ Sum as $\%$ of total } & 96 & $77(80.2 \%)$ & $13(13.5 \%)$ & $41(42.7 \%)$ & $2(2.1 \%)$ \\
\hline \multirow[t]{6}{*}{ Peri-urban } & Usoma & SW & 4 & $4(100 \%)$ & $0(0.0 \%)$ & $0(0.0 \%)$ & $0(0.0 \%)$ \\
\hline & Kogony & SW & 4 & $4(100 \%)$ & $0(0.0 \%)$ & $4(100 \%)$ & $0(0.0 \%)$ \\
\hline & \multirow[t]{3}{*}{ Otonglo } & SW & 8 & $8(100 \%)$ & $0(0.0 \%)$ & $8(100 \%)$ & $2(25.0 \%)$ \\
\hline & & $\mathrm{SP}$ & 1 & $1(100 \%)$ & $0(0.0 \%)$ & $0(0.0 \%)$ & $1(100 \%)$ \\
\hline & & $\mathrm{BH}$ & 1 & $1(100 \%)$ & $1(100 \%)$ & $1(100 \%)$ & $0(0.0 \%)$ \\
\hline & Sum as $\%$ of total & & 18 & $18(100 \%)$ & $1(5.0 \%)$ & $13(72.2 \%)$ & $3(17.0 \%)$ \\
\hline
\end{tabular}

SW: shallow well, SP: spring, BH: borehole

Wall lining and method of well protection

The study revealed that all BHs (100\%) had both concrete sealing or cover and wall lining, making them fully protected, while $34 \%$ of the SWs had wall linings, and $66 \%$ had none (Table 4 ). The percentage of wells with wall lining in the urban informal and peri-urban settlements was $27.3 \%$ and $64.7 \%$, respectively. Table 4 also shows the nature of spring water protection $(\mathrm{n}=11)$, where only $36.4 \%$ of the Sps were protected. Moreover, the table presents more aspects of water source improvements like drainage characteristics, presence of outflow water pipe, and whether seasonal or permanent during drier seasons. Analysis of correlation established a significant positive correlation $\left(\mathrm{R}^{2}=0.44 ; P=0.022\right)$ between $\mathrm{SW}$ wall protection and well depth.

\section{Analysis of sanitation types and characteristics in proximity to water sources}

The major types of facilities identified were: VIP, TPL, septic tank or flush toilets (S/F), and ecological sanitation (ECOSAN) facilities (Figure 3). TPL was the most dominant in the study area, distributed as follows: Manyatta A (43\%), Manyatta B (63\%), Nyalenda A (72\%), Nyalenda B (50\%), Obunga (74\%), and Usoma, Kogony and Otonglo at 53\%, 19\% and 60\%. Among the urban informal settlements, Nyalenda B had the largest number of VIP toilets, accounting for $40 \%$ of all the facilities studied. The least VIP was registered in Manyatta B and Nyalenda A. There were about $3 \%$ and $1 \%$ ECOSAN facilities in Manyatta B and Nyalenda B, respectively.

The study also assessed the extent of the sharing of facilities; the result shows a higher extent of pit latrines among different households in the urban informal settlements than in the peri-urban settlements. In terms of numbers, the results for the urban slums show the following: Nyalenda A (19.5\%), Manyatta A (19\%), Nyalenda B (17\%), Manyatta B (16\%), and Obunga (15\%), while the peri-urban results showed Usoma (4\%), Kogony (2\%), and Otonglo (6\%).

An analysis of proximity density (number of facilities within $15 \mathrm{~m}$ and $30 \mathrm{~m}$ radii of water sources) between sanitation facilities and water sources is pre- 
Table 4. Description of the conditions and protection of shallow wells and springs (excluding boreholes) in the study area

\begin{tabular}{|c|c|c|c|c|c|c|}
\hline Settlement & Site & Number & Protected & $\begin{array}{l}\text { Concrete } \\
\text { drainage }\end{array}$ & $\begin{array}{l}\text { Outflow } \\
\text { pipe }\end{array}$ & $\begin{array}{r}\text { Seasonality } \\
\text { (permanent) }\end{array}$ \\
\hline & & SWs $(n=$ & & & & \\
\hline \multirow[t]{5}{*}{ Urban informal } & Nyalenda B & 24 & $6(26.1 \%)$ & $3(12.5 \%)$ & Nil & $14(58.0 \%)$ \\
\hline & Nyalenda A & 17 & $1(6.0 \%)$ & $0(0.0 \%)$ & Nil & $8(57.0 \%)$ \\
\hline & Manyatta B & 14 & $5(35.7 \%)$ & $4(28.5 \%)$ & Nil & $8(55.0 \%)$ \\
\hline & Manyatta A & 7 & $6(85.7 \%)$ & $3(43.0 \%)$ & Nil & $3(43.0 \%)$ \\
\hline & Obunga & 22 & $5(22.7 \%)$ & $2(10.0 \%)$ & Nil & $10(45.0 \%)$ \\
\hline \multirow[t]{5}{*}{ Peri-urban } & Usoma & 4 & $1(25.0 \%)$ & - & Nil & $1(25.0 \%)$ \\
\hline & Kogony & 4 & $2(50.0 \%)$ & $2(50.0 \%)$ & Nil & $1(25.0 \%)$ \\
\hline & Otonglo & 8 & $8(88.9 \%)$ & $7(78.9 \%)$ & Nil & $2(22.2 \%)$ \\
\hline & Sum as $\%$ of total & 100 & $34(34.0 \%)$ & $21(21.0 \%)$ & - & $47(47.0 \%)$ \\
\hline & & Springs ( 1 & & & & \\
\hline \multirow[t]{3}{*}{ Urban informal } & Nyalenda B & 6 & $3(50.0 \%)$ & $2(33.3 \%)$ & $2(33.3 \%)$ & $2(33.3 \%)$ \\
\hline & Nyalenda A & 3 & $1(33.3 \%)$ & $1(33.3 \%)$ & $1(33.3 \%)$ & $3(100 \%)$ \\
\hline & Obunga & 1 & $0(0.0 \%)$ & $1(100 \%)$ & $0(0.0 \%)$ & $1(100 \%)$ \\
\hline \multirow[t]{2}{*}{ Peri-urban } & Otonglo & 1 & $0(0.0 \%)$ & $0(0.0 \%)$ & $0(0.0 \%)$ & $0(0.0 \%)$ \\
\hline & Sum as $\%$ of total & 11 & $4(36.4 \%)$ & $4(36.4 \%)$ & $4(36.4 \%)$ & $6(54.5 \%)$ \\
\hline
\end{tabular}

Nil: no presence of outflow pipe, SWs: Shallow wells

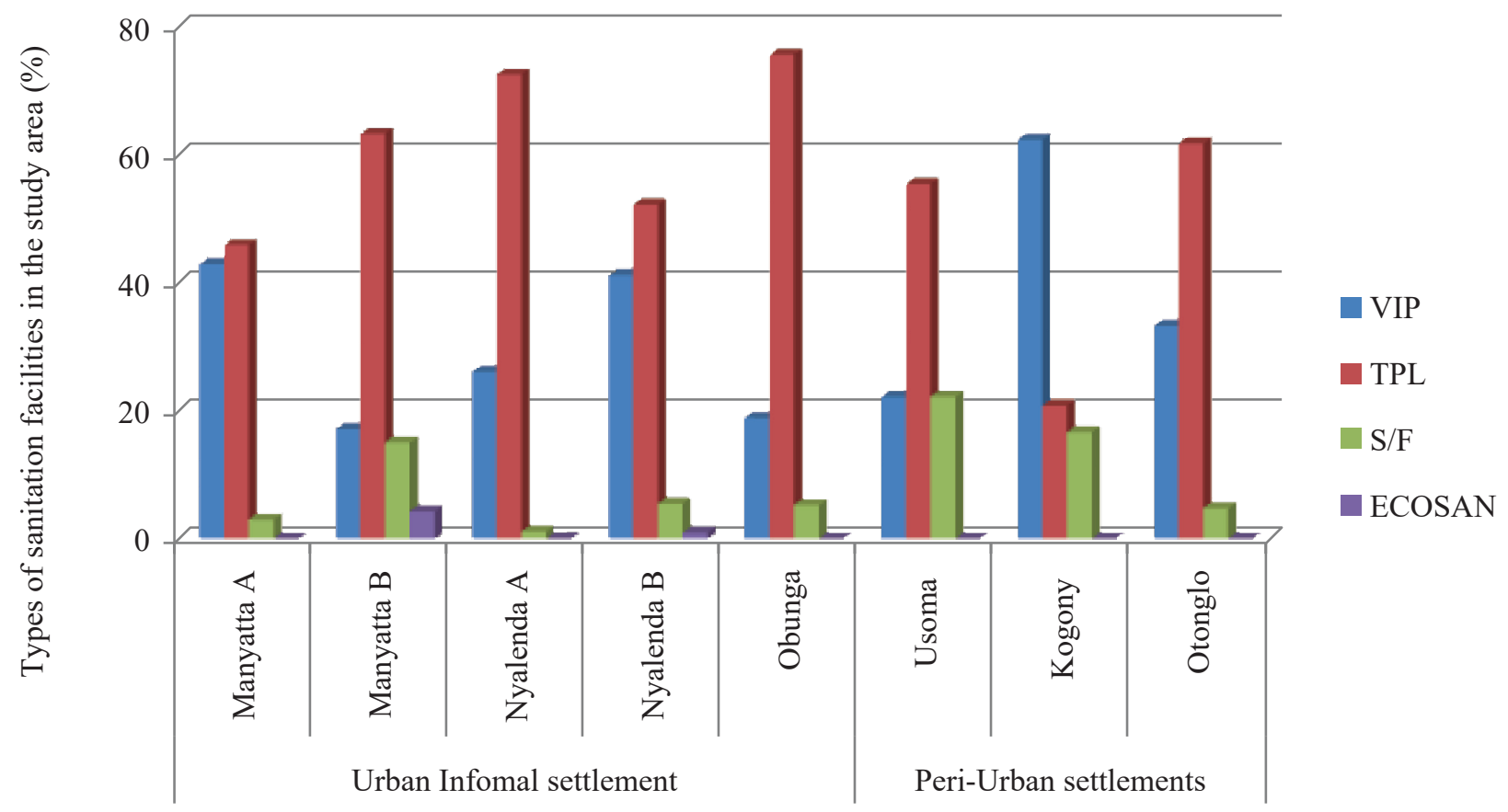

Figure 3. Summary of types of facilities in the study area of interest. VIP: ventilated improved pit latrine, TPL: traditional pit latrine, S/F: septic tank or flush toilets, ECOSAN: ecological sanitation. 
sented in Table 5. This approach was useful in understanding both the density of facilities within the settlements as well as in understanding the potential impacts of the facilities on neighbourhood water sources. The results show the following: a) at $15 \mathrm{~m}$ proximity to $\mathrm{SW}$, higher latrine density ranges were recorded in Nyalenda A (2.5) and Manyatta B (2.1), followed closely by Nyalenda B (1.8), then Obunga (1.6) and Manyatta A (1.4). The aggregate sanitation density for the urban informal settlements was 1.9 for $15 \mathrm{~m}$ radius. Generally, the mean sanitation density for the peri-urban areas were lower (0.3) compared to the urban informal settlements (1.9). The density at $30 \mathrm{~m}$ proximity followed a similar trend, except that instead of Nyalenda A, Manyatta B and Obunga took the lead at 6.4 and 4.8 , respectively, for the urban informal settlements. Nyalenda A followed at a distant third (4.1), then Manyatta A and Nyalenda B, with 4.0 and 2.4, respectively. There was a constant sanitation density (2.0) across all the SWs in the three settlements in the peri-urban areas.

Proximity sanitation densities for Sps and $\mathrm{BHs}$ across the study area are presented in the same table. The results show that Nyalenda B had the highest sanitation density around $\mathrm{Sps}$ at $15 \mathrm{~m}$ and $30 \mathrm{~m}$ proximity (4.8 and 6.7), while Otonglo had the least, at 2.0 and 3.0, respectively. For BHs, no settlement had more than one sanitation facility within a $15 \mathrm{~m}$ radius of each $\mathrm{BH}$, but Manyatta A had the highest number of facilities (density $=4.0$ ) at $30 \mathrm{~m}$ proximity density of a $\mathrm{BH}$. More interestingly, however, this study revealed a relatively high density of latrines around Sps, with some areas (i.e. Nyalenda B) having more than SWs (density of 4.8 against 1.8 , and 6.7 against 2.4 , at $15 \mathrm{~m}$ and $30 \mathrm{~m}$ radius, respectively).

\section{Discussion}

Characteristics of water sources and sanitation facilities in the study area

There were two main objectives formulated for this study: firstly, the characterization of water and sanitation facilities, with the aim of highlighting the exist-

Table 5. Analysis of proximity density of sanitation facilities to water sources in $15 \mathrm{~m}$ and $30 \mathrm{~m}$ radii of water points in the study area

\begin{tabular}{|c|c|c|c|c|c|}
\hline \multirow[b]{2}{*}{ Settlement } & \multirow[b]{2}{*}{ Site } & \multirow[b]{2}{*}{$\begin{array}{l}\text { Type of Water } \\
\text { Source }\end{array}$} & \multirow[b]{2}{*}{$\begin{array}{l}\text { Number of water } \\
\text { sources }(n=114)\end{array}$} & \multicolumn{2}{|c|}{ Proximity density at $15 \mathrm{~m}$ and $30 \mathrm{~m}$ radii } \\
\hline & & & & $15 \mathrm{~m}$ & $30 \mathrm{~m}$ \\
\hline \multirow[t]{11}{*}{ Urban informal } & \multirow[t]{2}{*}{ Nyalenda B } & SW & 24 & 1.8 & 2.4 \\
\hline & & $\mathrm{SP}$ & 6 & 4.8 & 6.7 \\
\hline & \multirow[t]{2}{*}{ Nyalenda A } & SW & 17 & 2.5 & 4.1 \\
\hline & & SP & 3 & 2.0 & 3.3 \\
\hline & \multirow[t]{2}{*}{ Manyatta B } & SW & 14 & 2.1 & 6.4 \\
\hline & & $\mathrm{BH}$ & 1 & 1.0 & 3.0 \\
\hline & \multirow[t]{2}{*}{ Manyatta A } & SW & 7 & 1.4 & 4.0 \\
\hline & & $\mathrm{BH}$ & 1 & 1.0 & 4.0 \\
\hline & \multirow[t]{2}{*}{ Obunga } & SW & 22 & 1.6 & 4.8 \\
\hline & & SP & 1 & 2.0 & 4.0 \\
\hline & \multicolumn{2}{|l|}{ Cumulative average } & & 2.0 & 4.3 \\
\hline \multirow[t]{6}{*}{ Peri-urban } & Usoma & SW & 3 & 0.0 & 2.0 \\
\hline & Kogony & SW & 3 & 0.0 & 2.0 \\
\hline & \multirow[t]{3}{*}{ Otonglo } & SW & 10 & 1.0 & 2.0 \\
\hline & & SP & 1 & 2.0 & 3.0 \\
\hline & & $\mathrm{BH}$ & 1 & 1.0 & 1.0 \\
\hline & Cumulative average & & & 0.3 & 2.0 \\
\hline
\end{tabular}

Proximity sanitation density around water source $=($ No. of sanitation facilities/No. of water source points). cumulative mean or average = sum of sanitation densities across all settlements/number of settlements. SW: Shallow well, SP: spring, BH: borehole 
ing baseline conditions; and finally, the assessment of proximity density of sanitation facilities within $15 \mathrm{~m}$ and $30 \mathrm{~m}$ for potential cross-contamination impacts. On water source characterization, our study revealed that SWs remain critical water sources in the informal settlements; the large number of SWs in the informal settlements and the large number of users attest to this fact. Nyalenda B, for instance, an area of less than 4 $\mathrm{km}^{2}$, had $24 \mathrm{SWs}$ and $6 \mathrm{Sps}$. In some areas, a single SW attracted over 500 users; an example is Nyalenda A, where 600 users relied on one SW during the dry season. Although the facilities and users were more in the urban informal settlements, the numbers were relatively less in the peri-urban areas. The important role of these SWs was further underscored by the fact that the majority of informal residents put them to the most trusted uses, such as cooking (42.7\%), laundry and cleaning (80.2\%), and even drinking (13.5\%). For the peri-urban areas, a greater number used these water sources for drinking compared to their counterparts in the urban slums. Generally, SWs and BHs in the periurban settlements are deeper, and deeper wells tend to be fuller and protected. This could perhaps explain the reasons for the increased confidence in the use of such wells in the peri-urban areas for more sensitive uses like drinking.

The high reliance on SWs, Sps and BHs in the urban informal settlements - commonly known as slums further attests to the growing social and economic depravities characterising urban informal settlements in developing countries, of which Kisumu is an example [41]. Informal settlements are known to host large populations of the urban poor and vulnerable residents. Most of these settlements offer home to many poor city immigrants seeking employment and cheap labour in these cities [44]. Some of these settlements also occupy areas of poor hydrology, high water table and frequent flood-risks and other environmental vulnerabilities, factors reported as responsible for the prevalence of SWs and poorly constructed pit latrines in these slums [27, 38]. Poor hydrological conditions limit the construction depth achievable and also the durability of facilities [43], and these conditions are essentially true of Kisumu's urban informal settlements [44]. The existing concern is that the situation in the informal settlements may grow worse with increased urbaniza- tion and rural-urban migration, and there is likely to be more congestion in the slums, more pressure on existing facilities and more danger of shared facilities and frequency of filling of pit latrines that would potentially present huge challenges to public health.

Additionally, the majority of the SWs in the study were characterized as non-improved or non-protected, and few have either wall linings or concrete top covers, meaning a high susceptibility to contamination. Deeper wells were found to have better protection than shallower ones, as shown by the positive correlation $\left(R^{2}=0.44\right)$, a scenario that explains why the peri-urban wells were deeper and better protected than those in the urban slums. The study, moreover, established that, due to lack of protection on most SWs and Sps, all sorts of abstraction techniques were in use, the hand drawn abstraction method remaining dominant. Interestingly, the negative correlation $\left(\mathrm{R}^{2}=\right.$ 0.60 ) found to exist between hand drawn abstraction methods and depth of SWs generally indicated that the deeper the well the less the HD methods applied, essentially meaning that deeper wells are safer from contaminations arising from HD. The problem with the HD technique is that the rope used might hide harmful microorganisms or act as a potential breeding ground for pathogens, and there is continuous exposure to surface contamination during HD.

\section{Sanitation density around water points and Implications on community health}

Our findings on proximity sanitation density analysis near water sources established high numbers of pit latrines around water sources (Table 5), with about two and four pit latrines within $15 \mathrm{~m}$ and $30 \mathrm{~m}$ radius to water sources in the urban and peri-urban informal settlements, respectively. The pressure is even more on Sps, as records show in Nyalenda B and Manyatta A. Previous research has shown that biological and chemical pollutants could leach through the underground soil into wells, BHs or Sps if the proximity is close. A study by Aidoo confirmed a negative correlation between bacterial load in water and the distance between the pit latrine and water sources [45]. The same study revealed a much greater risk of contamination on SWs as opposed to deeper wells, and that the risk increases during the rainy seasons when the aquifer is "topped 
up" more rapidly and contaminant migrations are accelerated. The WHO provides recommendations for safe distances from pit latrines to the nearest critical environmental resources such as SWs and Sps; for instance, it is recommended that a pit latrine should at least be $30 \mathrm{~m}$ from a shallow water well, $\mathrm{BH}$ or $\mathrm{Sp}$, and at least $2 \mathrm{~m}$ above an underlying water table [34]. This means that the proximity density findings from our study are in violation of this requirement, and, obviously, a public health concern.

The problems with close proximity of sanitation to water sources are that most pit latrines, as already seen, are traditional, with poor state of construction, and highly prone to frequent filling and emptying. The emptying processes, especially in the urban informal settlements, are rather rudimentary and unhygienic [46], as many residents cannot afford expensive emptying/exhauster services. Residents sometimes open an even shallower open pit adjacent to the filled TPL where contents are directly transferred from the filled pit into the new opened one. Sometimes the pit content is emptied into an open drainage channel or sewage flow [23]. These practices put adjacent water sources at great risk, considering that most of these water sources are highly depended on by the majority of residents. Nonetheless, there is a significant uptake of VIPs and ECOSAN in the area, albeit to a smaller percentage $(<30 \%)$ on average.

\section{Conclusions and Recommendations}

This study found that SWs and Sps remain critical water sources in the study area. However, most of the water sources are shallow and unprotected, despite their use for critical services such as cooking and drinking. Uses and usage of water sources may reflect prevailing water supply conditions in an area; overdependence on a given water source might be an indication of water stress, lack of alternative water sources, or inadequacies in municipal water supplies. Residents might be relying on SWs simply because they have no affordable municipal water supply. Water usage is an important public health concern, especially where the use is a potential route of contaminant exposure. The study also found that most residents use pit latrines sited without due consideration of the safe distance rec- ommendations by the WHO for possible contaminant control. These results reflect the underlying water and sanitation problems of major pro-poor informal settlements not only in Kenya, but across many urban centres in the developing world. With the growing urban population, which might translate to increased growth of the urban informal settlements, more sustainable and improved sanitation solutions are needed to protect these informal settlements.

The study makes the following recommendations to Kisumu: (a) community-led sensitization programs targeted at improving awareness of improved toilet facilities and general public hygiene; and, (b) development of compelling regulations through bylaws to ensure SWs in the slums are protected and sited at safe distances from toilet facilities; and in the long run, a more targeted intervention to improve municipal water supply and sewerage services in the informal settlements as a way of eradicating overreliance on SWs and pit latrines.

\section{Acknowledgements}

The field work was supported by the African water and sanitation project (AfriWatSan). The AfriWatSan project (Project No: AQ140023) is funded by the Royal society capacity building initiative and the UK department for international development (DFID). The views expressed and information contained in this paper are not necessarily those of or endorsed by the funders, hence they are not liable to accept responsibility for the views or information presented herein nor for any reliance placed on them. We further acknowledge the support of Mr. Francis who acted as the community liaison and guide, fellow project mates and the support of my employer, the Co-operative University of Kenya.

\section{Conflict of Interest}

The authors have no conflicts of interest to declare.

\section{References}

1. Murungi C \& Blokland MW (2016): Benchmarking for the provision of water supply and sanitation services 
to the urban poor: An assessment framework. International Journal of Water 10 (2/3): 155-174. https://doi. org/10.1504/IJW.2016.075566

2. World Health Organization \& the United Nations Children's Fund (WHO/UNICEF) (2017): Progress on Drinking Water, Sanitation and Hydrology 2017 Update and SDG Baselines. WHO, Geneva $110 \mathrm{pp}$

3. Sengupta S, Verma S \& Kazmi S (2018): Bottom to the Fore: Rural sanitation in Sub-Saharan Africa. Centre for Science and Environment, New Delhi. https:// www.cseindia.org/bottom-to-the-fore-8624 (Accessed May 25, 2020)

4. Kwiringira J, Atekyereza P, Niwagaba C et al (2016): Seasonal variations and shared latrine cleaning practices in the slums of Kampala city, Uganda. BMC Public Health 16(1): 361. https://doi.org/10.1186/s12889016-3036-7

5. Price HD, Okotto LG, Okotto-Okotto J, Pedley S \& Wright J (2018): A participatory methodology for future scenario analysis of sub-national water and sanitation access: Case study of Kisumu, Kenya. Water Int 43(5): 591-602. https://doi.org/10.1080/02508060.20 18.1500343

6. Scott P, Cotton A \& Khan MS (2013): Tenure security and household investment decisions for urban sanitation: The case of Dakar, Senegal. Habitat Int 40: 5864. https://doi.org/10.1016/j.habitatint.2013.02.004

7. Tilley E, Ulrich L, Lüthi C, Reymond P \& Zurbrügg C (2014): Compendium of Sanitation Systems and Technologies. 2nd revised ed. Swiss Federal Institute of Aquatic Science and Technology (Eawag), Dübendorf, Switzerland pp 10-13

8. Cairncross S, Hunt C, Boisson S et al (2010): Water, sanitation and hygiene for the prevention of diarrhoea. Int J Epidemiol 39 (suppl 1): i193-i205. https://doi.org/ 10.1093/ije/dyq035

9. Howard G, Calow R, MacDonald A \& Bartram J (2016): Climate change and water and sanitation: Likely impacts and emerging trends for action. Annu Rev Environ Resour 41: 253-276. https://doi.org/10.1146/ annurev-environ-110615-085856

10. World Health Organization (WHO) (2015): Sanitation Safety Planning: Manual for Safe Use and Disposal of Wastewater, Greywater and Excreta. WHO, Geneva $138 \mathrm{pp}$

11. Wasonga J, Olang'o CO \& Kioli F (2014): Improving households knowledge and attitude on water, sanitation, and hygiene practices through school health programme in Nyakach, Kisumu County in Western Kenya. Journal of Anthropology 2014: 958481 https:// doi.org/10.1155/2014/958481

12. Horn LM, Hajat A, Sheppard L et al (2018): Association between precipitation and diarrheal disease in Mozambique. Int J Environ Res Public Health 15(4): 709. https://doi.org/10.3390/ijerph15040709

13. Lapworth DJ, Nkhuwa DCW, Okotto-Okotto J et al (2017): Urban groundwater quality in sub-Saharan Africa: Current status and implications for water security and public health. Hydrogeol J 25(4): 1093-1116. https://doi.org/10.1007/s10040-016-1516-6

14. Othoo CO \& Abrahams WP (2016): Importance of contaminated soils in supplying bioaccessible fluoride to grazing animals from the historic metalliferous mining areas of the UK. Journal of Health and Environmental Research 2(5): 27-33 https://doi.org/10.11648/j. jher.20160205.11

15. Abila R, Mutemi M, Mutuku E, Mutati K, Mutinda M \& Musyoka CM (2012): Physico-chemical and bacteriological quality assessment of shallow wells in Kitui town, Kenya. JEnviron Sci Water Resources 1(2): 27-33. http://hdl.handle.net/123456789/2564 (Accessed September 23, 2019)

16. Wagah GG, Onyango GM \& Kibwage JK (2010): Accessibility of water services in Kisumu municipality, Kenya. J Geogr Reg Plann 3(4): 114-125

17. Opisa S, Odiere MR, Jura WGZ, Karanja DMS \& Mwinzi PNM (2012): Faecal contamination of public water sources in informal settlements of Kisumu City, western Kenya. Water Sci Technol 66(12): 2674-2681. https://doi.org/10.2166/wst.2012.503

18. Kiptum CK \& Ndambuki JM (2012): Well water contamination by pit latrines: A case study of Langas. Int J Water Res Environ Eng 4(2): 35-43

19. WHO \& UNICEF (2015): Progress on Sanitation and Drinking Water: 2015 Update and MDG assessment. WHO, Geneva, Switzerland p12. https://reliefweb.int/ report/world/progress-sanitation-and-drinking-water2015-update-and-mdg-assessment (Accessed May 24, 2020)

20. Government of Kenya (GOK) (2016): Kenya Environmental Sanitation and Hygiene Strategic Framework (KESSF) 2016-2020. https://www.wsp.org/sites/wsp. 
org/files/publications/Kenya $\% 20$ Environmental $\% 20$ Sanitation $\% 20$ and $\% 20$ Hygiene $\% 20$ Strategic $\% 20$ Framework.pdf (Accessed April 12, 2020)

21. Kimani-Murage EW \& Ngindu AM (2007): Quality of water the slum dwellers use: The Case of a Kenyan slum. JUrban Health 84(6): 829-838. https://doi.org/10.1007/ s11524-007-9199-x

22. Simiyu S, Swilling M, Rheingans R \& Cairncross $S$ (2017): Estimating the cost and payment for sanitation in the informal settlements of Kisumu, Kenya: A cross sectional study. Int J Environ Res Public Health 14(1): 49. https://doi.org/10.3390/ijerph14010049

23. Okotto L, Okotto-Okotto J, Price H, Pedley S \& Wright J (2015): Socio-economic aspects of domestic groundwater consumption, vending and use in Kisumu, Kenya. Appl Geogr 58: 189-197. https://doi.org/10.1016/j.apgeog. 2015.02.009

24. Wright JA, Cronin A, Okotto-Okotto J, Yang H, Pedley S \& Gundry SW (2013): A spatial analysis of pit latrine density and groundwater source contamination. Environ Monit Assess 185(5): 4261-4272. https://doi. org/10.1007/s10661-012-2866-8

25. Okotto-Okotto J, Okotto L, Price H, Pedley S \& Wright J (2015): A longitudinal study of long-term change in contamination hazards and shallow well quality in two neighbourhoods of Kisumu, Kenya. Int J Environ Res Public Health 12(4): 4275-4291

26. Herman T (2017): Quality of Water in Relation to Diarrheal Disease Incidence in Obunga. Independent Study Project(ISP) Collection. 2653. https://digitalcollections. sit.edu/isp_collections/2653 (Accessed April 22, 2019)

27. Maoulidi M(2010): A water and sanitation needs assessment for Kisumu city, Kenya. https://doi.org/10.7916/ D8SJ1TJ5

28. Douglas I, Alam K, Maghenda M, McDonnell Y, McLean L \& Campbell J (2008): Unjust waters: Climate change, flooding and the urban poor in Africa. Environ Urban 20(1): 187-205. https://doi.org/10.1177/ 0956247808089156

29. Jakeman AJ, Barreteau O, Hunt RJ et al (2016): Integrated groundwater management: An overview of concepts and challenges. In: Integrated Groundwater Management: Concepts, Approaches and Challenges. (Jakeman A, Barreteau O, Hunt R, Rinaudo JD \& Ross $\mathrm{A}, e d)$. Springer International Publishing, Cham, Switzerland pp4-12. DOI: 10.1007/978-3-319-23576-9
30. Kamra SK \& Rao KVGK (1996): Environmental aspects of subsurface drainage projects. In: Water-Quality Hydrology. Water Science and Technology Library, vol 16. (Singh VP \& Kumar B, ed). Springer, Dordrecht, Netherlands pp265-285. https://doi.org/10.1007/978-94-0110393-0_16

31. Lagardien A \& Muanda C (2014): An Approach Towards Developing Technical Sanitation Solutions for Informal Settlements. Water Research Commission, Gezina, South Africa pp 16-18

32. Garn JV, Sclar GD, Freeman MC et al (2017): The impact of sanitation interventions on latrine coverage and latrine use: A systematic review and meta-analysis. Int J Hyg Environ Health 220(2): 329-340. https://doi.org/ 10.1016/j.ijheh.2016.10.001

33. Graham JP \& Polizzotto ML (2013): Pit latrines and their impacts on groundwater quality: A systematic review. Environ Health Perspect 121(5): 521-530. https://doi.org/10.1289/ehp.1206028

34. World Health Organization (WHO) (2017): Fact Sheet on Simple Pit Latrines. Fact sheets on Environmental Sanitation. WHO, Geneva pp 17-28. http://www. who.int/water_sanitation_health/hygiene/emergencies/ fs3_4.pdf (Accessed February 24, 2019)

35. Morgan P (2007): Available Sanitation Technologies for Rural and Peri-urban Africa. Stockholm Environment Institute (SEI), Stockholm. https://www.sswm. info/node/5369 (Accessed March 27, 2018)

36. Kenya National Bureau of Statistics (KNBS) (2020): 2019 Kenya Population and Housing Census: Volume II-Distribution of Population by Administrative Units. ISBN: 978-9966-102-11-9. https://www. knbs.or.ke/?wpdmpro=2019-kenya-population-andhousing-census-volume-ii-distribution-of-populationby-administrative-units (Accessed March 25, 2020)

37. Wagah GG, Obange N \& Ogindo HO (2018): Food poverty in Kisumu, Kenya. In: Urban Food Systems Governance and Poverty in African Cities. (Battersby $\mathrm{J} \&$ Watson $\mathrm{V}, e d)$. Routledge, London p 223

38. Olago D, Marshall M, Wandiga SO et al (2007): Climatic, socio-economic, and health factors affecting human vulnerability to cholera in the Lake Victoria Basin, East Africa. Ambio 36(4): 350-358. https://doi. org/10.1579/0044-7447(2007)36[350:CSAHFA]2.0. $\mathrm{CO} ; 2$

39. Rakama SO, Obiri JF \& Mugalavai EM (2017): Evalu- 
ation of land use change pattern of Kajulu-Riat hill periurban area near Kisumu City, Kenya. IJSRIT 4(7): 42-52

40. County Government of Kisumu (COK) (2018): Kisumu County Urban Institutional Development Strategy (CUIDS) Kisumu City 2018-19. Kisumu, Kenya. https:/www.kisumu.go.ke/wp-content/uploads/2019/08/ Kisumu-County-Urban-Institutional-DevelopmentStrategy-CUIDS-2018-2019-final.pdf (Accessed October 14, 2019)

41. Bard F \& Lennmalm J (2015): Development Plan for Sub-Centres in Kisumu - A Conceptual Proposal for Sustainable Urban Development in Kisumu, Kenya. Department of Civil and Environmental Engineering, Division of Construction Management, Chalmers University of Technology, Göteborg, Sweden p22

42. Hamill L \& Bell FG (2013): Groundwater Resource Development. revised ed. Elsevier, Amsterdam pp 11-41. https://books.google.com/books/about/Groundwater_ Resource_Development.html?id=jP8bBQAAQBAJ (Accessed May 5, 2020)
43. Waller RM (1988): Ground Water and the Rural Homeowner. U.S Government Printing Office, Washington, D.C. $37 \mathrm{pp}$

44. Maoulidi M (2012): Kisumu Millennium Development Goals Multi-Sector Household Survey. Earth Institute, Columbia University, New York pp 20-32

45. Aidoo AE (2013): Effect of pit latrines on dug-well water quality - a case study of the Asankrangwa community in the Wassa Amenfi west district of Ghana. Kwame Nkrumah University of Science and Technology, Kumasi, Ghana pp34-36. http://dspace.knust.edu. gh/bitstream/123456789/6179/1/AIDOO\%20ABEKAH \%20ERNEST.pdf (Accessed January 24, 2018)

46. Adane M, Mengistie B, Kloos H, Medhin G \& Mulat W (2017): Sanitation facilities, hygienic conditions, and prevalence of acute diarrhea among under-five children in slums of Addis Ababa, Ethiopia: Baseline survey of a longitudinal study. PLoS One 12(8): e0182783. https://doi.org/10.1371/journal.pone.0182783

J UOEH $42(3): 237-249(2020)$ 